\title{
The effects of increasing amounts of milk replacer powder added to whole milk on passage rate, nutrient digestibility, ruminal development, and body composition in dairy calves
}

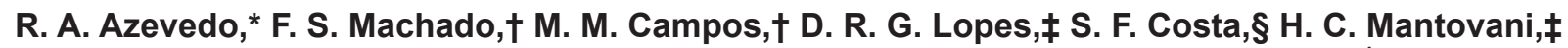 \\ F. C. F. Lopes,† M. I. Marcondes,\# L. G. R. Pereira,† T. R. Tomich,† and S. G. Coelho*1 \\ *Department of Animal Science, School of Veterinary Medicine, Federal University of Minas Gerais, Minas Gerais, 30161-970, Brazil \\ †Embrapa Dairy Cattle, Minas Gerais, 36038-330, Brazil \\ †Department of Microbiology, Federal University of Viçosa, Minas Gerais, 36570-000, Brazil \\ $\S$ Department of Veterinary Medicine, Federal University of Lavras, Minas Gerais, 37200-000, Brazil \\ \#Department of Animal Science, Federal University of Viçosa, Minas Gerais, 36570-000, Brazil
}

\begin{abstract}
The aim of this study was to evaluate the effects on feed intake, calf performance, feed efficiency, fecal score, passage rate, apparent nutrient digestibility, development of rumen and other organs, and body composition of increasing the total solids content of liquid feed (whole milk) by adding increasing amounts of milk replacer powder during the preweaning period. Crossbred Holstein-Gyr calves $(\mathrm{n}=32)$ were assigned to 1 of 4 treatments ( $\mathrm{n}=8$ per group), which consisted of different total solids concentrations: 12.5, 15.0, 17.5, and $20.0 \%$ of liquid feed. Calves received $6 \mathrm{~L}$ of liquid per day, divided into 2 equal meals (0800 and 1600 h) and provided in buckets, from 5 to $55 \mathrm{~d}$ of age. Starter and water were provided ad libitum during the entire experiment. At $56 \mathrm{~d}$ of age, animals were killed. Laboratory analysis determined that the actual total solids contents of the liquid feed were 13.5, 16.1, 18.2, and $20.4 \%$, for the proposed $12.5,15.0,17.5$, and $20.0 \%$ total solids treatments, respectively. The osmolality of liquid feed treatments was 265 to $533 \mathrm{mOsm} / \mathrm{L}$. Fecal score was similar among treatments, except for wk 2 and 7. Intake of liquid feed was similar among treatments from 6 wk of age. During wk 4, 5, and 6, we detected a linear decrease in starter intake. After wk 7 , we observed greater starter intake for calves fed approximately $16.1 \%$ total solids. Water intake, feed efficiency, and withers height were similar among treatments. Increasing concentrations of total solids in liquid feed quadratically affected average daily gain, final body weight, and empty body weight. We observed a greater average daily gain for calves fed approximately $20.4 \%$ total solids. Passage rate, nutrient digestibility,
\end{abstract}

Received May 5, 2016.

Accepted July 17, 2016

${ }^{1}$ Corresponding author: sandragesteiracoelho@gmail.com development of pre-stomachs and intestine, and body composition were similar among treatments. Increasing the concentration of total solids in liquid feed up to $20.4 \%$ reduced starter intake between 4 and 6 wk of life, but increased average daily gain. It did not affect passage rate, nutrient digestibility, ruminal and organ development, or body composition in calves during the preweaning period, indicating that this strategy may be a viable alternative for feeding without increasing the total volume of liquid feed provided to dairy calves. Key words: calf performance, feed intake, preweaning, total solids

\section{INTRODUCTION}

Restricting liquid feed intake to approximately $10 \%$ of calf BW during the preweaning period is a common practice in calf-rearing systems (Jasper and Weary, 2002; Terré et al., 2009; Sweeney et al., 2010) and, when associated with early weaning, it can reduce feed costs and stimulate the early onset of starter intake (Eckert et al., 2015; Yavuz et al., 2015; Chapman et al., 2016). However, solid feed intake in the first month of life may be low (Sweeney et al., 2010) and, when combined with a liquid feed restriction regimen, can limit calf performance (Khan et al., 2007a). This condition can explain the hunger behavioral characteristics demonstrated by dairy calves (De Paula Vieira et al., 2008; Miller-Cushon et al., 2013).

Conflicting results are found in the literature related to the performance of calves fed a greater volume of liquid feed versus calves fed conventionally (OmidiMirzaei et al., 2015). The greater supply of liquid feed may (Kristensen et al., 2007) or may not (Khan et al., 2007b; Silper et al., 2014) have negative effects on rumen development, and may reduce (Terré et al., 2007; Hill et al., 2010; Chapman et al., 2016) or not reduce (Silva et al., 2015) apparent nutrient digestibility. One 
way to partially overcome the negative effects of providing greater volumes of liquid feed is to add products commonly sold as "balancers" or milk replacer powder (MRP), which increase the TS content in the liquid without increasing the amount of milk feed (Glosson et al., 2015). Terré et al. (2006) have reported that calves fed a greater volume of enriched liquid feed (18\% TS) had higher BW, but with a lower starter intake and an apparent delay in rumen development compared with conventionally fed calves (12.5\% TS). Glosson et al. (2015) reported that $17.6 \%$ TS in a greater volume of liquid feed, increased ADG, BW, and feed efficiency.

Recommendations for the maximal concentration of TS in liquid feed are still not well-established, and further research on the effects of different concentrations of TS in liquid feed on calf performance and development are needed. Tikofsky et al. (2001) determined the effect of varying concentrations of dietary fat and carbohydrate on changes in body composition of Holstein calves fed under isocaloric and isonitrogenous intake conditions. Although dietary fat varied among treatments without compromising ADG and final BW, body composition was altered by diet, demonstrating that the evaluation of animals based only on ADG does not reflect the efficacy of feeding regimens for dairy calves. An evaluation is needed of the effects of different feeding regimens on digestibility, and on rumen development, and body composition in calves. We are unaware of data showing the effects on passage rates in preweaned calves of increasing TS concentrations in liquid feed by adding MRP in whole milk.

The final osmolality of a liquid feed must also be considered. When osmolality increases, it can lead to digestive problems (Kertz and Loften, 2013). According to Glosson et al. (2015), an increase in osmolality resulting from the addition of milk balancer to whole milk can affect water absorption by the intestines, leading to an increase in incidence of diarrhea. According to McGuirk (2003), normal serum osmolality is about 280 to $290 \mathrm{mOsm} / \mathrm{kg}$, and milk is an isosmotic food. Although reference values are not well-established, fluids with an osmolality $>600 \mathrm{mOsm} / \mathrm{L}$ should be offered with caution (McGuirk, 2003), because the gradient is no longer as effective, and absorption in the small intestine is inhibited, possibly leading to osmotic diarrhea (Floren et al., 2016). Feeding concentrations may be as important to calf health as the total nutrients offered, and care should be taken to not concentrate replacers to the point where they might be harmful (Floren et al., 2016).

The objective of this study was to evaluate the effects of increasing concentrations of TS in whole milk on feed intake, performance, feed efficiency, body frame development, fecal score, passage rate, apparent nutrient digestibility, development of the rumen and other organs, and body composition in dairy calves during the preweaning period. Our hypothesis was that increasing TS concentrations in whole milk by adding MRP would alter feed intake and performance, indirectly affecting fecal score, passage rate, apparent nutrient digestibility, development of the rumen, and body composition.

\section{MATERIALS AND METHODS}

This study was approved by the Ethics Committee of Embrapa Dairy Cattle, Brazil (protocol no. 06/2014). The experiment was conducted at the Embrapa Dairy Cattle Experimental Farm, located in Coronel Pacheco, Minas Gerais, Brazil.

\section{Animals, Housing, and Treatments}

Holstein $\times$ Gyr crossbred male calves $(\mathrm{n}=32)$ were used; their genetic composition was $5 / 8$ or more Holstein and $3 / 8$ or less Gyr. Calves were born during Brazilian fall (April to May 2014), removed from their dams, fed $3 \mathrm{~L}$ of colostrum (>50 g/L of $\operatorname{IgG})$ within 6-8 h of birth, and transferred to individual shelters over tropical grass pasture (Cynodon spp.) for the study period. Blood samples were collected via jugular venipuncture within $48 \mathrm{~h}$ after birth. Samples were centrifuged at $800.6 \times g$ for 10 min to measure total serum protein using a refractometer (Serum protein REF-301; Biocotek, Beilun, Ningbo, China).

Between 2 and $4 \mathrm{~d}$ of age, calves were fed $6 \mathrm{~L} / \mathrm{d}$ of transition milk divided into 2 equal meals offered at 0800 and $1600 \mathrm{~h}$. At $5 \mathrm{~d}$, calves were assigned to 1 of 4 treatment groups ( $\mathrm{n}=8$ per group), maintaining a balance of birth BW and genetic composition in each group. Treatments consisted of increasing amounts of MRP (Sprayfo Violet SSP, Deventer, the Netherlands; Table 1$)$ added to $6 \mathrm{~L} / \mathrm{d}$ of whole milk $(12.6 \pm 0.7 \%$ TS; mean \pm SD; Table 1 ) to adjust the TS to expected concentrations of $12.5,15.0,17.5$, and $20.0 \%$ of liquid feed. The initial TS content in the whole milk was measured daily, immediately after milking and before each feeding, using a Brix refractometer (DD-3 Palm Abbe Digital, Misco, Solon, OH). Brix grade values were converted to TS content using the equation proposed by Moore et al. (2009) $[\mathrm{TS}=0.9984 \times($ Brix refractometer reading +2.077$]$, and the amount of MRP to be added to the whole milk was adjusted to achieve the desired TS content for each treatment. The MRP was added to the whole milk immediately before it was supplied to the calves. The time between milking and feeding the calves was not more than $30 \mathrm{~min}$. 
Table 1. Nutrient composition (DM basis, \% unless otherwise noted) of whole milk, milk replacer powder (MRP), starter, and treatments

\begin{tabular}{|c|c|c|c|c|c|c|c|}
\hline \multirow[b]{2}{*}{ Nutrient } & \multirow[b]{2}{*}{ Whole milk } & \multirow[b]{2}{*}{$\mathrm{MRP}^{1}$} & \multirow[b]{2}{*}{ Starter } & \multicolumn{4}{|c|}{ Treatment (\% TS in whole milk) } \\
\hline & & & & 13.5 & 16.1 & 18.2 & 20.4 \\
\hline$\overline{\mathrm{DM}^{2}}$ & 12.6 & 94.7 & 89.3 & 13.5 & 16.1 & 18.2 & 20.4 \\
\hline $\mathrm{CP}$ & 25.6 & 20.0 & 21.2 & 25.2 & 23.8 & 23.2 & 22.9 \\
\hline Ether extract & 33.0 & 13.4 & 2.1 & 33.0 & 28.6 & 26.0 & 23.7 \\
\hline Ash & - & 7.3 & 11.9 & 5.8 & 5.6 & 5.5 & 5.3 \\
\hline Lactose $^{3}$ & 33.9 & 47.0 & - & 31.5 & 39.6 & 42.5 & 44.8 \\
\hline Gross energy (Mcal/kg) & - & 4.5 & 3.7 & 5.8 & 5.7 & 5.6 & 5.6 \\
\hline
\end{tabular}

The total volume of treatment $(6 \mathrm{~L} / \mathrm{d})$ was divided into 2 equal meals (0800 and $1600 \mathrm{~h}$ ) and provided to calves in buckets from 5 to $55 \mathrm{~d}$ of age. Starter (Soylac Rumen $20 \%$ CP, flaked corn, and the rest of ingredients pelleted; Total Alimentos, Três Corações, Minas Gerais, Brazil; Table 1) and water were offered ad libitum throughout the experimental period. The amount of starter provided was sufficient to result in $10 \%$ orts.

\section{Handling and Health Measurements}

At $8 \mathrm{~d}$ of age, preventive oral treatment against coccidiosis was performed (Baycox Ruminants; Bayer, Leverkusen, Germany), at $3 \mathrm{~mL} / 10 \mathrm{~kg}$ of BW.

Health and fecal scores were monitored daily by trained farm staff. Fecal scores were assigned according to Larson et al. (1977), as follows: 1, normal (firm but not hard); 2, soft (does not hold form, piles but spread slightly); 3, runny (spreads readily to about $6 \mathrm{~mm}$ depth); and 4, watery (liquid consistency, splatters). A calf was considered to have diarrhea if the fecal score was 3 or 4 .

\section{Intake, Performance, and Growth}

Calves' performance, body frame development, and feed intake were monitored between 5 and $55 \mathrm{~d}$ of age. Intake of whole milk + MRP mixture, starter, and water was calculated daily by subtracting refusals from the amounts provided. The total intake of DM, CP, and gross energy from starter and whole milk + MRP were calculated. Water intake was measured using a portable balance (WH-A04; WeiHeng, Yongkang, China); no bucket reference was used to evaluate evaporation.

Starting at $5 \mathrm{~d}$ of age, BW and body frame development (withers height and heart girth) were measured once a week before morning feeding. Feed efficiency was calculated using the ratio between ADG and total DMI (Khan et al., 2007a).

\section{Gastrointestinal Passage Rate and Nutrient Apparent Digestibility}

Between 43 at $47 \mathrm{~d}$ of age, total gastrointestinal tract passage rate was estimated using a chromic oxide $\left(\mathrm{Cr}_{2} \mathrm{O}_{3}\right)$ external marker (Castells et al., 2013). Before the morning liquid feeding, all calves received a single oral dose of $2 \mathrm{~g}$ of chromic oxide in a gelatin capsule. Fecal samples were taken manually from the rectum at $0,4,8,12,16,20,24,28,32,36,40,48,56,64$, 72,84 , and $96 \mathrm{~h}$ after receiving the marker. Samples were stored at $-20^{\circ} \mathrm{C}$ immediately after collection for subsequent chromium determination (atomic emission spectrum). Fractional passage rate in the rumen $\left(\boldsymbol{K}_{r}\right)$ and cecum $\left(\boldsymbol{K}_{c}\right)$, transit time in the tubular compartment of the gastrointestinal tract, total mean retention time in the rumen, total mean retention time postrumen, and total mean marker retention time in the gastrointestinal tract were calculated according to the multicompartmental model proposed by Dhanoa et al. (1985).

Between 50 and $55 \mathrm{~d}$ of age, all animals were submitted to an apparent nutrient digestibility trial with a $5 \mathrm{~d}$ total feces collection. Plastic bags were attached to each animal to collect feces according to Terré et al. (2007). Bags were changed 6 times per day, and feces were weighed every day for each calf and stored at $-20^{\circ} \mathrm{C}$ for further analysis. During the digestibility trial, a few animals had diarrhea; in these cases, fecal samples were excluded. For each day of fecal collection, total feces per calf were weighed, homogenized, and sampled. During the digestibility trial, samples of 
liquid feed, starter, and refusals for each calf were also sampled, pooled for the $5 \mathrm{~d}$ period, and stored in plastic containers until analysis.

\section{Slaughter, Gastrointestinal Tract, Internal Organs, and Viscera Weight}

At $56 \mathrm{~d}$ of age, all calves were transported $(135 \mathrm{~km})$ in a livestock trailer to the Federal University of Viçosa (Minas Gerais, Brazil), and were slaughtered after being deprived of solid food for $14 \mathrm{~h}$. Calves were killed by captive bolt, followed by jugular venipuncture for exsanguination (Silva et al., 2015). After slaughter, the abdominal cavity was immediately opened, and each region of the gastrointestinal tract (reticulo-rumen, omasum, abomasum, and small and large intestines) was isolated, tied off, and weighed. After samples were collected from the gastrointestinal tract, it was emptied, washed with running water (to remove contents), and weighed. Internal organs and viscera were also weighed. All variables were evaluated as a proportion of empty BW.

\section{Ruminal and Cecum pH, Ruminal Ammonia Nitrogen, and Ruminal and Cecum Organics Acids}

The rumen and cecum were immediately isolated after slaughter, preventing reflux and contamination of samples. Ruminal and cecum $\mathrm{pH}$ were measured immediately after separation of the components of the gastrointestinal tract from the carcass using a portable potentiometer with a puncture electrode (DM-2-Digimed, São Paulo, Brazil). Rumen and cecum content were collected separately, and ruminal contents were filtered through 4 layers of cheesecloth to separate the liquid and solid fractions. All samples were stored in plastic tubes at $-20^{\circ} \mathrm{C}$ for further analysis. Ammonia nitrogen in ruminal contents was determined according to the colorimetric assay proposed by Chaney and Marbach (1962). Absorbance was measured at $630 \mathrm{~nm}$ in a Spectronic 20D spectrophotometer (Thermo Fisher Scientific, Madison, WI), and ammonium chloride $\left(\mathrm{NH}_{4} \mathrm{Cl}\right)$ was used as a standard.

Organic acids were determined by HPLC in a Dionex Ultimate 3000 Dual Detector HPLC (Dionex Corporation, Sunnyvale, CA) coupled to a Shodex RI-101 refractive index detector (ECOM Ltd., Prague, Czech Republic) maintained at $40^{\circ} \mathrm{C}$ using a Phenomenex Rezex ROA ion exchange column (Phenomenex, Torrance, $\mathrm{CA}$ ), $300 \times 7.8 \mathrm{~mm}$, maintained at $45^{\circ} \mathrm{C}$. The mobile phase was prepared with $5 \mathrm{mmol} / \mathrm{L} \mathrm{H}_{2} \mathrm{SO}_{4}$, and the flow rate was $0.7 \mathrm{~mL} / \mathrm{min}$. All samples $(2 \mathrm{~mL})$ were defrosted at room temperature $\left(25^{\circ} \mathrm{C}\right)$ and centrifuged $(12,000 \times g, 10 \mathrm{~min})$, and the cell-free supernatants were treated as described by Siegfried et al. (1984). The following organic acids were used to calibrate the standard curve: acetic, succinic, formic, lactic, propionic, valeric, isovaleric, isobutyric, and butyric acids. Organic acids were prepared to a final concentration of $10 \mathrm{mmol} / \mathrm{L}$, except isovaleric acid $(5 \mathrm{mmol} / \mathrm{L})$ and acetic acid $(20 \mathrm{mmol} / \mathrm{L})$.

\section{Gastrointestinal Tract Development}

An area of $5 \mathrm{~cm}^{2}$ from the ventral ruminal sac, omasum laminae, and different regions of the small intestine (duodenum, jejunum, and ileum) were fixed in formalin and routinely processed for paraffin embedding. The paraffin blocks were sectioned using an Olympus CUT 4055 manual microtome (Olympus, Tokyo, Japan) into $5 \mu \mathrm{m}$-thick serial sections. For morphometric analysis, slides were stained with hematoxylin-eosin as described by Luna (1968). Images were captured using a light microscope (CX31; Olympus), attached to a camera (OSIS SC30; Olympus), using Cell-B software (Olympus). Morphometric analyses were performed using AxioVision 4.8.2-06/2010 software (Carl Zeiss Images Systems, Jena, Germany). The measurements taken were (1) the area and height of ruminal and omasal papillae and intestinal villi in different regions of the small intestine; and (2) the depth of the intestinal glands. To determine mitotic index, 2,000 cells from the basal layer of the rumen and omasum epithelium were counted, including those with nuclei presenting mitotic figures (using the light microscope, 400× magnification). Mitotic index was calculated as a ratio between the number of nuclei in division and the total number of nuclei (Costa et al., 2008; Azevedo et al., 2013). Cell proliferation in different regions of the small intestine was determined by counting the mitotic figures in the intestinal gland epithelium, in 10 fields, using a $40 \times$ objective and $10 \times$ eyepiece $(400 \times$ magnification).

\section{Body Composition}

After slaughter, the reticulo-rumen, omasum, abomasum, small and large intestines, internal fat, mesentery, liver, heart, kidneys, lung, tongue, spleen, diaphragm, esophagus, trachea, reproductive tract, members, head, blood, and half carcass were ground for approximately $20 \mathrm{~min}$ in an industrial grinder to make a composite and homogeneous sample, and samples were stored and frozen at $-20^{\circ} \mathrm{C}$ for further analysis.

\section{Nutritional Composition Analysis}

Milk samples were collected twice a day (morning and afternoon) and analyzed for TS using an infra- 
red analyzer (Bentley 2000; Bentley Instruments Inc., Chaska, MN).

Samples from liquid feed treatments were collected daily, composed by month, and lyophilized for nutritional composition (AOAC, 1990; Table 1). The osmolality of the liquid feed was measured using an osmometer (Micro-Osmette, Natick, MA). Samples of the starter and MRP were collected weekly and composed by month. Feces samples were pre-dried in a forced-ventilation oven $\left(55^{\circ} \mathrm{C}\right)$ for $72 \mathrm{~h}$ and ground in a 1-mm sieve. Body component samples (non-carcass + carcass components) were pre-dried by lyophilization and ground in a 1-mm sieve in a knife mill (Detmann et al., 2012).

All samples were analyzed for DM (method 934.01), CP (method 988.05), ether extract (method 920.39), and ash (method 942.05) according to the AOAC (1990). Gross energy was determined by an adiabatic bomb calorimeter (Parr Instrument Company, Moline, IL).

\section{Statistical Analysis}

Data were analyzed using SAS version 9.0 (SAS Institute Inc., Cary, NC). Weekly averages of feed intake, performance, and body frame development were analyzed using a repeated-measures mixed model (PROC MIXED), including calf as the random component and treatment, week, and their interaction as fixed components. Differences among treatments were assessed using orthogonal polynomial contrasts to estimate the linear, quadratic, and cubic effects of increasing the concentrations of TS in the liquid feed. Fecal score by period was tested as a nonparametric variable using the Kruskal-Wallis test with 95\% confidence intervals for treatment comparisons (PROC NPAR1WAY). The mean per period and variables with a single measurement during the study (such as final BW) were analyzed by using the GLM procedure with orthogonal polynomial contrasts to estimate the linear, quadratic, and cubic effects of increased TS concentration in the liquid feed. We analyzed BW at birth and total serum protein using ANOVA, including treatment as a fixed effect and using a Tukey adjustment for $P$-values. Least squares means for each treatment are reported. The variables BW at birth and total serum protein were considered covariates. Significance was declared at $P$ $\leq 0.05$.

\section{RESULTS AND DISCUSSION}

The actual concentrations of TS in the whole milk + MRP were $13.5 \pm 0.53 \%, 16.1 \pm 0.03 \%, 18.2 \pm 0.14 \%$, and $20.4 \% \pm 0.24 \%$ for the proposed diets of 12.5, 15.0, 17.5 , and $20.0 \%$ TS, respectively. The composition of treatments is described in Table 1 . The difference between the TS content initially proposed and the values found by laboratory analysis may have occurred because the equation used to convert Brix grade values to TS content was designed based on waste milk samples (Moore et al., 2009), which are different from the whole milk used in this experiment.

Birth BW (36.8 $\pm 4.46 \mathrm{~kg}$; Table 2) and passive transfer of immunity were similar among treatments. We evaluated the passive transfer of immunity based on total serum protein at $24 \mathrm{~h}$ after colostrum feeding,

Table 2. Feed and water intake, performance, feed efficiency, and body frame development of calves ( $\mathrm{n}=8$ per group) fed different TS contents in whole milk during the preweaning period ( 5 to $55 \mathrm{~d}$ of age)

\begin{tabular}{|c|c|c|c|c|c|c|c|c|}
\hline \multirow[b]{2}{*}{ Item } & \multicolumn{4}{|c|}{ Treatment (\% TS in whole milk) } & \multirow[b]{2}{*}{ SEM } & \multicolumn{3}{|c|}{$P$-value } \\
\hline & 13.5 & 16.1 & 18.2 & 20.4 & & Treatment & Week & $\begin{array}{c}\text { Treatment } \\
\text { week }\end{array}$ \\
\hline \multicolumn{9}{|l|}{ Intake } \\
\hline Whole milk $+\mathrm{MRP}^{1}$ (as fed, $\mathrm{kg} / \mathrm{d}$ ) & 6.0 & 5.9 & 5.9 & 5.6 & 0.03 & 0.01 & 0.01 & 0.01 \\
\hline Whole milk + MRP (g of DM/d) & 810 & 958 & 1,064 & 1,142 & 22.9 & 0.01 & 0.01 & 0.01 \\
\hline Starter $(\mathrm{g}$ of $\mathrm{DM} / \mathrm{d})$ & 106 & 190 & 111 & 76 & 12.0 & 0.01 & 0.01 & 0.01 \\
\hline Total gross energy (Mcal/kg per day) & 5.2 & 6.0 & 6.2 & 6.4 & 0.1 & 0.01 & 0.01 & 0.03 \\
\hline Water $(\mathrm{kg} / \mathrm{d})$ & 1.6 & 2.4 & 1.8 & 2.3 & 0.2 & 0.37 & 0.01 & 0.95 \\
\hline \multicolumn{9}{|l|}{ Performance } \\
\hline Birth BW (kg) & 37.7 & 37.1 & 36.1 & 36.1 & 0.79 & 0.88 & - & - \\
\hline Final BW (kg) & 70.4 & 82.7 & 82.2 & 80.8 & 1.37 & 0.01 & - & - \\
\hline $\operatorname{ADG}(\mathrm{g} / \mathrm{d})$ & 694 & 876 & 852 & 903 & 21.2 & 0.01 & 0.01 & 0.57 \\
\hline Feed efficiency & 0.73 & 0.76 & 0.73 & 0.74 & 0.01 & 0.33 & 0.01 & 0.36 \\
\hline
\end{tabular}

${ }^{1} \mathrm{MRP}=$ milk replacer powder. 
which averaged $7.2 \pm 1.10 \mathrm{~g} / \mathrm{dL}$ for all animals. Almost all calves $(97 \%)$ had values above $5.5 \mathrm{~g} / \mathrm{dL}$. All calves remained healthy and had no signs of illness during the experiment.

Fecal score (Figure 1a) was similar among treatments, except for wk 2 and 7 . The increase in fecal score of calves fed pasteurized milk containing milk balancer can be explained by the higher osmolality of the liquid feed (280-483 mOsm/L), which may affect water absorption in the intestines (Glosson et al., 2015). In the present study, osmolality was 265, 351, 439, and 533 $\mathrm{mOsm} / \mathrm{L}$ for the treatments with $13.5,16.1,18.2$, and $20.4 \%$ TS, respectively. However, fecal score increased (linearly, $P=0.01$; Figure 1a) with TS concentration only in wk 2 and 7 , indicating that the increase in osmolality (up to $533 \mathrm{mOsm} / \mathrm{L}$ ) did not affect fecal scores, as reported by Floren et al. (2016). Moreover, in wk 2, the highest fecal scores occurred along with diarrhea caused by pathogens that affect calves at this age, regardless of treatment; in wk 7, a possible explanation was stress caused by the study of passage rate, as well as indicators used to measure passage rate.

\section{Intake, Performance, and Growth}

We observed an interaction $(P=0.01$; Table 2$)$ between treatment and weeks for intake of whole milk $+\operatorname{MRP}(\mathrm{kg} / \mathrm{d})$. During wk 2, 3, and 5, we detected a decrease (linearly, $P=0.01$ ) in intake of whole milk + MRP $(\mathrm{kg} / \mathrm{d})$ as TS concentration increased in the liquid feed. After wk 6, we observed a similar intake of whole milk + MRP $(\mathrm{kg} / \mathrm{d}$ ) among treatments (Figure 1b). However, intake of whole milk + MRP (g DM/d) increased (linearly, $P=0.01$ ) with TS concentration in the liquid feed, as initially proposed in the experimental design. Even with the reduction in liquid feed intake $(\mathrm{kg} / \mathrm{d})$ before wk 6 , the increase in TS concentration by the addition of MRP to whole milk was an effective strategy for providing more nutrients (g DM/d) during the preweaning period.

Regardless of TS concentration in the liquid feed, calves were able to ingest all liquid feed provided only after wk 7 (Figure 1b). This indicated a physical limitation to intake capacity in all groups. The observed reduction in feed liquid intake (wk 2, 3, and 5) with increasing TS concentrations in the liquid feed indicated a chemostatic limitation in the groups with greater amounts of TS (Figure 1b). Silper et al. (2014) also reported that calves were not able to ingest a total volume of 4 or $6 \mathrm{~L} / \mathrm{d}$ of milk replacer (MR) (12.5\% TS) in their first month.

We observed an interaction $(P=0.01$; Table 2$)$ between treatment and weeks for starter intake. During wk 2 and 3, starter intake was similar among treat- ments. During wk 4, 5, and 6, we detected a decrease (linearly, $P=0.01$ ) in starter intake as TS concentration increased in the liquid feed (Figure 1c). Previous studies showed that increasing TS through higher volumes of liquid feed reduced starter intake (Bach et al., 2013; Kiezebrink et al., 2015; Silva et al., 2015). After wk 7 , we observed a quadratic effect $(P=0.01)$ with the increase of TS concentration in the liquid feed (Table 2) and greater starter intake for calves fed approximately $16.1 \%$ TS (Figure 1c). This may also be related to chemostatic limitations caused by the increase in nutrient intake in the treatments with greater TS concentrations in the liquid feed, up to $16.1 \%$ TS. However, we observed low starter intake $(121 \pm 67 \mathrm{~g}$ of $\mathrm{DM} / \mathrm{d}$ ) regardless of treatment, possibly due to a hypophagic condition caused by the total volume $(6 \mathrm{~L} / \mathrm{d})$ of liquid feed offered in all treatments. Low starter intake during the preweaning period in intensive calf-rearing programs has been reported in other studies (Jasper and Weary, 2002; Overvest et al., 2016).

Analysis of total DMI (liquid feed DM + starter DM; $\mathrm{g}$ of $\mathrm{DM} / \mathrm{d})$ showed an interaction $(P=0.01)$ between treatment and weeks (Table 2). Between wk 3 and 6 , total DMI increased (linearly, $P=0.01$ ) with TS concentration. However, in the last 2 wk of the preweaning period, we observed a quadratic effect $(P=0.01)$ with the increase in TS concentration in the liquid feed, and greater DMI for calves fed approximately $18.2 \%$ TS (Figure 1d). We observed an interaction $(P=0.01$; Table 2) between treatment and weeks for gross energy (Mcal kg/d) and CP (g/d) intake (Table 2). Between wk 2 and 6, gross energy intake increased (linearly, $P=0.01$ ) with TS concentration (data not shown). During wk 2, 5, and 6, CP intake was similar among treatments (data not shown). Between wk 3 and 4 , CP intake increased (linearly, $P=0.01$ ) with TS concentration (data not shown). However, in the last 2 wk of the preweaning period, we observed a quadratic effect $(P=$ 0.01 ) for gross energy and CP intake with the increase in TS concentration in the liquid feed and greater starter intake for calves fed approximately $18.2 \%$ TS (data not shown).

Water intake was similar among treatments $(2.0 \pm 1.0$ $\mathrm{kg} / \mathrm{d}$; Table 2). Ternouth et al. (1985) did not observe any differences in water intake as TS concentration increased (17 to 26\%) in the liquid feed in calves up to 6 wk of age. Pettyjohn et al. (1963) reported a linear increase in water intake as TS concentration increased in the liquid feed. We observed a positive relationship between total DMI and water intake (Kertz et al., 1984). In the present study, calves fed $16.1 \%$ TS had a larger starter intake in the final weeks of the preweaning period (Figure 1c). The greater osmolality observed in the $20.4 \%$ TS $(533 \mathrm{mOsm} / \mathrm{L})$ may have resulted in 


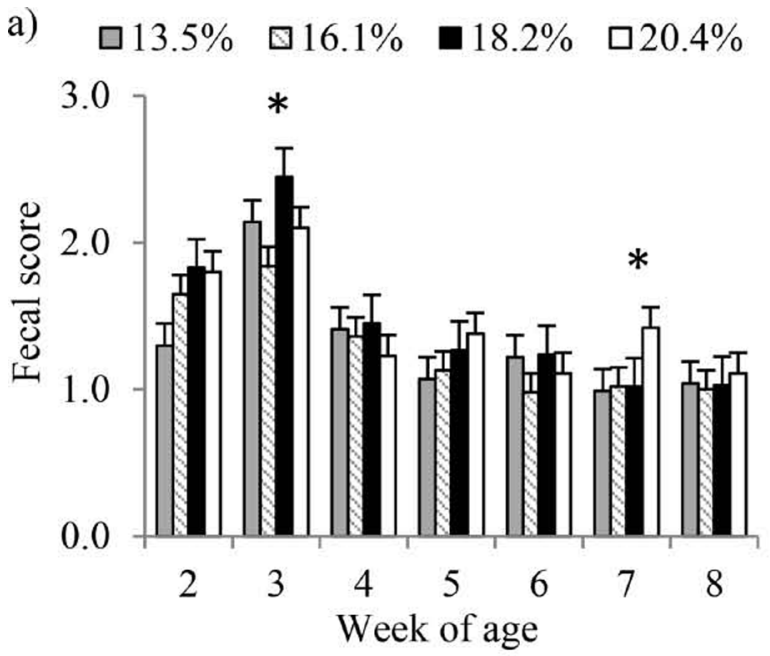

b) $\square 13.5 \% \quad \square 16.1 \% \quad \square 18.2 \% \quad \square 20.4 \%$

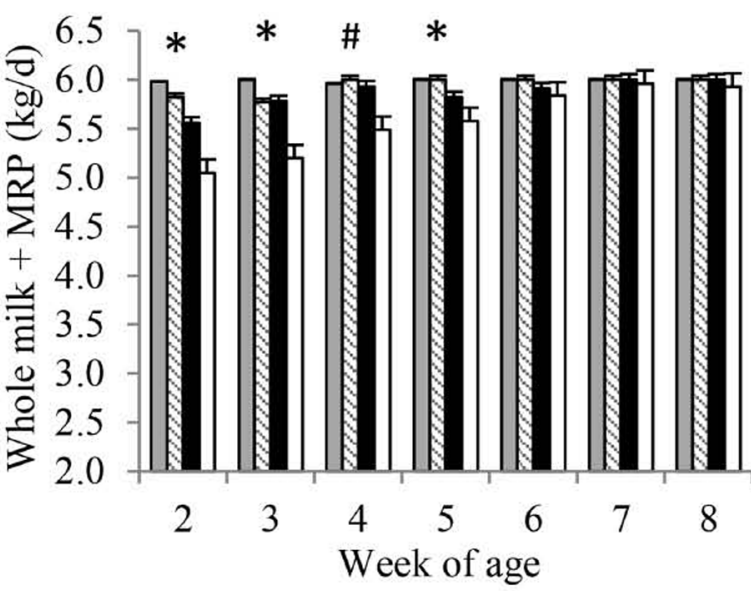

c) $\square 13.5 \% \quad \square 16.1 \% \quad \square 18.2 \% \quad \square 20.4 \%$

d) $\square 13.5 \% \quad \square 16.1 \% \quad \square 18.2 \% \quad \square 20.4 \%$
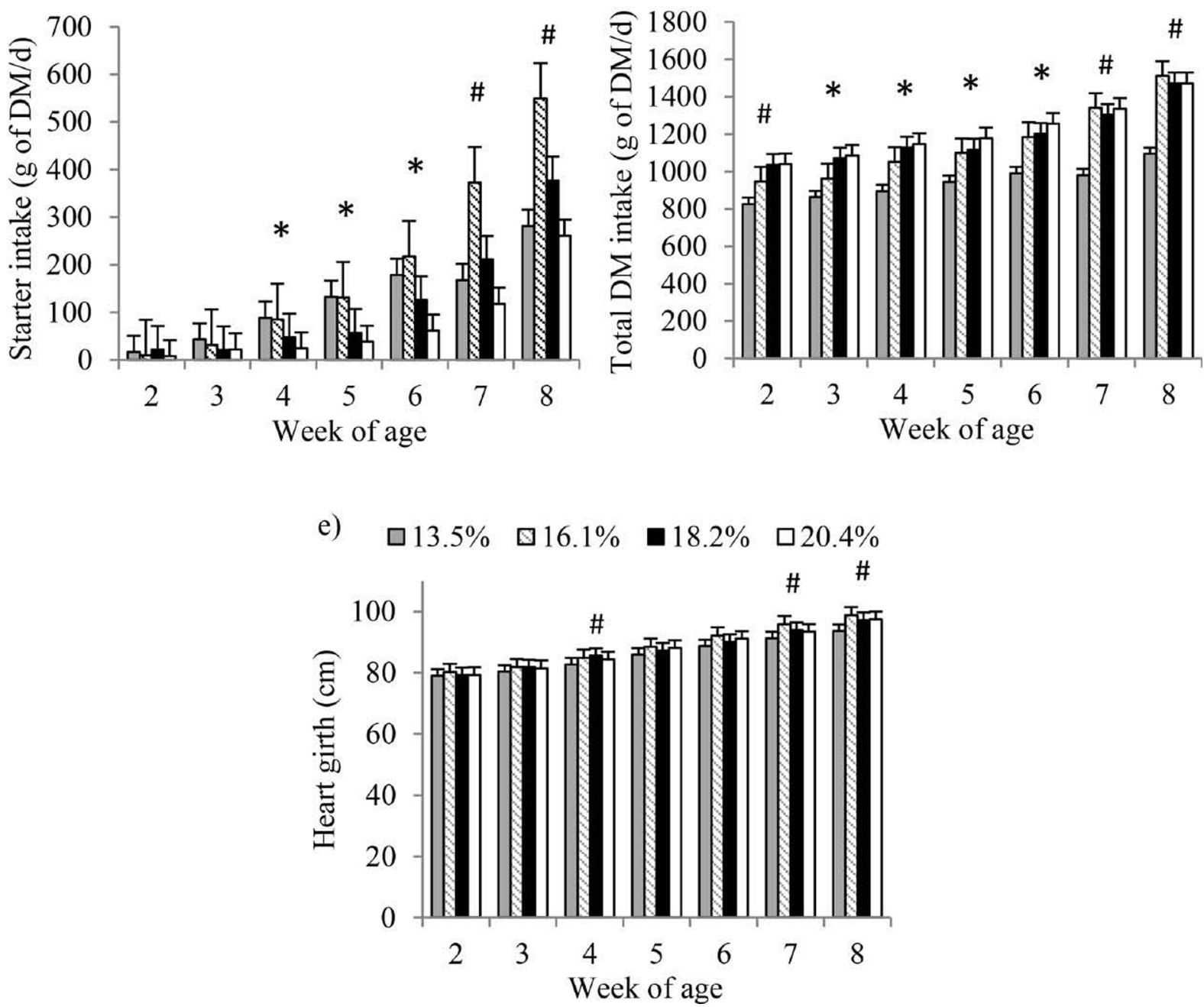

Figure 1. (a) Fecal score; (b) liquid feed [whole milk + milk replacer powder (MRP), $\mathrm{kg} / \mathrm{d}$ ] intake; (c) starter intake (g of DM/d); (d) total DMI ( $\mathrm{g}$ of DM/d); and (e) heart girth $(\mathrm{cm})$ of calves $(\mathrm{n}=8$ per group) fed different TS contents $(13.5,16.1,18.2$, and $20.4 \%)$ in whole milk during the preweaning period. ${ }^{*}$ Linear effect $(P \leq 0.05)$; \#quadratic effect. Error bars represent SE. 
more water intake to mitigate the concentration of TS, and may explain the similarity in water intake between the 16.1 and $20.4 \%$ TS groups (Table 2).

Feed efficiency and withers height were similar among treatments (Table 2). However, the increase in TS concentration in liquid feed had a quadratic effect $(P=$ 0.01) on $\mathrm{ADG}$, final $\mathrm{BW}$ at $55 \mathrm{~d}$ of age, and empty BW (Table 2). We observed greater ADG for calves fed $19.5 \%$ TS, approximately the highest TS concentration evaluated in the present study. Except for wk 4, 7 , and 8 , interactions $(P=0.01)$ between treatments and weeks (Table 2) for measurements of heart girth showed, similar heart girth among treatments. During wk 4 and after wk 7, we detected a quadratic effect $(P=0.01)$ on heart girth as the TS concentration increased in the liquid feed, and greater heart girth for calves fed approximately 18.2\% TS (Figure 1e).

These results can be explained by an increase in nutrient intake in calves fed liquid feed containing higher amounts of TS (Table 2). The optimum protein:energy ratio to maximize $\mathrm{ADG}$ of calves fed only $\mathrm{MR}$ is estimated at 48 to $50 \mathrm{~g} \mathrm{CP/Mcal} \mathrm{of} \mathrm{ME} \mathrm{(Blome} \mathrm{et} \mathrm{al.,}$ 2003; Bartlett et al., 2006), or 51 g of CP/Mcal of ME (low ME intake) at $55 \mathrm{~g} \mathrm{CP} / \mathrm{Mcal}$ of ME (high ME intake) for calves fed MR and pelleted starter (Hill et al., 2009). In the current experiment, the protein:energy ratios were 54, 49, 49, and $48 \mathrm{~g} \mathrm{CP} /$ Mcal of ME (ME calculated as $0.9 \times$ intake of total gross energy; Davis and Drackley, 1998; Bartlett et al., 2006), for 13.5, 16.1, 18.2, and $20.4 \%$ TS, respectively. The optimum protein:energy ratio to maximize ADG in calves fed whole milk + MRP and starter was estimated to be between 48 and $49 \mathrm{~g} \mathrm{CP} / \mathrm{Mcal}$ of ME. According to Blome et al. (2003) and Bartlett et al. (2006), the increase in calves' growth efficiency is attributed to an increase in body protein and water associated with lean mass that occurs when protein is provided in synchrony with energy.

\section{Gastrointestinal Passage Rate and Nutrient Apparent Digestibility}

No differences in fractional passage rate in the rumen $\left(K_{r}\right)$ and cecum $\left(K_{c}\right)$, transit time in the tubular compartment of the gastrointestinal tract, total mean retention time in rumen, total mean retention time post-rumen, and in total mean marker retention time in the gastrointestinal tract were observed among treatments (Table 3 ). These results may be explained by the low starter intake observed for all treatments. It is important to acknowledge that higher DMI should result in greater passage rate (Huhtanen and Kukkonen, 1995; Castells et al., 2013). We are unaware of other studies showing the effects on the passage rate of preweaned calves of increasing TS concentration in liquid feed by the addition of MRP to whole milk. Our objective was to assess solids passage rate as an indirect assessment of the feeding system in the development of the digestive tract of calves. We encourage integrated research efforts to evaluate the separate passage rate only with whole milk + MRP with a liquid marker, and further studies are needed to better understand the effect of TS in liquid feed and starter intake on these parameters.

The DM, OM, CP, and gross energy apparent digestibility were similar among treatments (Table 4), which may be because all calves were fed the same amount of liquid feed $(6 \mathrm{~L} / \mathrm{d})$ composed mainly of whole milk, which has high digestibility, and they all had low starter intake. The increase in nutrient digestibility in calves receiving greater amounts of whole milk (Silva et al., 2015), the reduction in nutrient digestibility in calves receiving greater amounts of MR (Hill et al., 2010; Chapman et al., 2016), and the results of the present study showed that increased TS concentration in the liquid feed composed of whole milk + MRP could be an option for avoiding the decrease in nutrient digestibility observed when greater amounts of liquid feed based

Table 3. Fractional passage rates of the external marker in the gastrointestinal tract of calves $(\mathrm{n}=8$ per group) fed different TS contents in whole milk during the preweaning period (5 to $55 \mathrm{~d}$ of age)

\begin{tabular}{|c|c|c|c|c|c|c|c|}
\hline \multirow[b]{2}{*}{ Item $^{1}$} & \multicolumn{4}{|c|}{ Treatment (\% TS in whole milk) } & \multirow[b]{2}{*}{ SEM } & \multicolumn{2}{|c|}{ Contrast, $P$-value } \\
\hline & 13.5 & 16.1 & 18.2 & 20.4 & & Linear & Quadratic \\
\hline$\overline{K_{r}\left(\mathrm{~h}^{-1}\right)}$ & 0.06 & 0.05 & 0.05 & 0.07 & 0.005 & 0.48 & 0.22 \\
\hline$K_{c}\left(\mathrm{~h}^{-1}\right)$ & 0.33 & 0.24 & 0.38 & 0.37 & 0.029 & 0.30 & 0.43 \\
\hline TT (h) & 1.81 & 2.37 & 1.54 & 1.56 & 0.175 & 0.35 & 0.48 \\
\hline TRTR (h) & 15.44 & 20.48 & 22.12 & 17.02 & 1.583 & 0.68 & 0.14 \\
\hline TRTPR (h) & 3.23 & 4.01 & 3.37 & 2.75 & 0.295 & 0.47 & 0.27 \\
\hline TMRT (h) & 20.55 & 26.86 & 27.59 & 23.10 & 1.707 & 0.61 & 0.15 \\
\hline
\end{tabular}

${ }^{1} K_{r}=$ fractional passage rate in the rumen; $K_{c}=$ fractional passage rate in the cecum; TT $=$ transit time in the tubular compartment of the gastrointestinal tract; TRTR = total mean retention time in rumen; TRTPR = total mean retention time post-rumen; TMRT $=$ total mean marker retention time in the gastrointestinal tract. 
Table 4. Nutrient apparent digestibility of calves ( $\mathrm{n}=8$ per group) fed different TS contents in whole milk during the preweaning period ( 5 to $55 \mathrm{~d}$ of age)

\begin{tabular}{|c|c|c|c|c|c|c|c|}
\hline \multirow[b]{2}{*}{ Item $(\%)$} & \multicolumn{4}{|c|}{ Treatment (\% TS in whole milk) } & \multirow[b]{2}{*}{ SEM } & \multicolumn{2}{|c|}{ Contrast, $P$-value } \\
\hline & 13.5 & 16.1 & 18.2 & 20.4 & & Linear & Quadratic \\
\hline $\mathrm{DM}$ & 84.9 & 86.3 & 87.0 & 88.0 & 0.52 & 0.07 & 0.85 \\
\hline $\mathrm{OM}$ & 87.7 & 87.9 & 88.5 & 89.7 & 0.43 & 0.17 & 0.60 \\
\hline $\mathrm{CP}$ & 85.5 & 88.4 & 88.4 & 88.3 & 0.45 & 0.07 & 0.15 \\
\hline Gross energy & 88.1 & 88.1 & 88.5 & 89.5 & 0.46 & 0.31 & 0.60 \\
\hline
\end{tabular}

on $\mathrm{MR}$ is provided to calves. However, less digestion in postweaning calves fed with greater amounts of liquid have been reported (Terré et al., 2007; Hill et al., 2010; Chapman et al., 2016), and additional studies are needed to better explain the effects of increasing TS in whole milk by the addition of MRP on digestibility in calves during the postweaning period.

\section{Gastrointestinal Tract, Internal Organs, and Viscera Weight}

The mass of reticulo-rumen, omasum, abomasum, small and large intestines were similar among treatments (Table 5). The lack of difference could be explained by the low starter intake observed in all treatments. The increase in total nutrient intake with the increase in TS concentration was not sufficient to determine an effect on gastrointestinal tract size. As reported by Baldwin et al. (2004), rumen development has a remarkable effect on the capacity and provision of digestive substrates for preruminant growth. The onset of solid feed intake and the establishment of anaerobic microbial ecosystem and ruminal fermentation promote ruminal physical and metabolic development (Baldwin et al., 2004; Khan et al., 2011). Silper et al. (2014) observed no differences in the ground starter intake and reticulo-rumen mass of calves fed $6 \mathrm{~L} / \mathrm{d}$ of liquid feed during the preweaning period. However, Kristensen et al. (2007) observed that the total weight of reticulorumen, omasum, and stomach of calves at $35 \mathrm{~d}$ of age decreased linearly with increasing amounts of MR (3.1, $4.8,6.6$, and $8.3 \mathrm{~kg} ; 12.3 \%$ TS).

The weight of all internal organs and viscera was similar among treatments (Table 5). According to Ferrell and Jenkins (1998), internal organs have a higher metabolic rate, and the liver responds to alterations in feeding patterns. However, we did not observe this in the current study, even with the increase in TS concentration in the liquid feed.

\section{Ruminal and Cecum pH, Ruminal Ammonia Nitrogen, Ruminal and Cecum Organics Acids, and Gastrointestinal Tract Development}

Ruminal and cecum $\mathrm{pH}$, the concentration of ruminal ammonia nitrogen and the proportion of VFA (\%) in the rumen and cecum, as well as the relationship between acetate and propionate and the total concentration of

Table 5. Weight (\% of empty BW) of internal organs and viscera of calves ( $\mathrm{n}=8$ per group) fed different TS contents in whole milk during the preweaning period (5 to $55 \mathrm{~d}$ of age)

\begin{tabular}{lcccccccc}
\hline & \multicolumn{3}{c}{ Treatment $(\%$ TS in whole milk) } & & \multicolumn{2}{c}{ Contrast, $P$-value } \\
\cline { 2 - 4 } Item & 13.5 & 16.1 & 18.2 & 20.4 & & SEM & Linear & Quadratic \\
\hline Empty BW (kg) & 69.8 & 80.5 & 79.0 & 80.1 & 1.43 & 0.01 & 0.04 \\
Organ weight (\% of empty BW) & & & & & & & \\
$\quad$ Reticulo-rumen & 1.09 & 1.20 & 1.14 & 1.06 & 0.043 & 0.67 & 0.25 \\
Omasum & 0.24 & 0.27 & 0.22 & 0.24 & 0.008 & 0.60 & 0.73 \\
Abomasum & 0.55 & 0.55 & 0.55 & 0.58 & 0.013 & 0.33 & 0.51 \\
Small intestine & 3.03 & 2.96 & 3.12 & 2.97 & 0.068 & 0.96 & 0.70 \\
Large intestine & 1.26 & 1.29 & 1.09 & 1.15 & 0.053 & 0.25 & 0.89 \\
Liver & 2.38 & 2.23 & 2.20 & 2.37 & 0.055 & 0.89 & 0.22 \\
Lungs & 1.32 & 1.40 & 1.24 & 1.42 & 0.035 & 0.71 & 0.46 \\
Spleen & 0.72 & 0.54 & 0.43 & 0.58 & 0.043 & 0.20 & 0.08 \\
Kidneys & 0.42 & 0.44 & 0.43 & 0.48 & 0.011 & 0.08 & 0.31 \\
Pancreas & 0.09 & 0.08 & 0.07 & 0.08 & 0.004 & 0.24 & 0.32 \\
Heart & 0.64 & 0.56 & 0.64 & 0.66 & 0.017 & 0.38 & 0.09 \\
Omental fat & 0.40 & 0.38 & 0.38 & 0.40 & 0.015 & 0.94 & 0.59 \\
Perirenal fat & 0.73 & 0.71 & 0.71 & 0.84 & 0.039 & 0.35 & 0.33 \\
\hline
\end{tabular}


Table 6. Ruminal and cecum $\mathrm{pH}$, ruminal ammonia nitrogen $\left(\mathrm{NH}_{3}\right)$, and organic acids in the rumen and cecum of calves ( $\mathrm{n}=8$ per group) fed different TS contents in whole milk during the preweaning period ( 5 to 55 d of age)

\begin{tabular}{|c|c|c|c|c|c|c|c|}
\hline \multirow[b]{2}{*}{ Item } & \multicolumn{4}{|c|}{ Treatment (\% TS in whole milk) } & \multirow[b]{2}{*}{ SEM } & \multicolumn{2}{|c|}{ Contrast, $P$-value } \\
\hline & 13.5 & 16.1 & 18.2 & 20.4 & & Linear & Quadratic \\
\hline \multicolumn{8}{|l|}{ Rumen } \\
\hline $\mathrm{pH}$ & 7.2 & 7.1 & 7.0 & 7.0 & 0.08 & 0.27 & 0.99 \\
\hline $\mathrm{NH}_{3}(\mathrm{mmol} / \mathrm{L})$ & 7.4 & 5.2 & 10.8 & 6.8 & 0.99 & 0.63 & 0.60 \\
\hline Acetate $(\%)$ & 45.6 & 47.5 & 44.2 & 43.1 & 0.71 & 0.06 & 0.27 \\
\hline Propionate (\%) & 23.6 & 22.1 & 22.5 & 22.1 & 0.82 & 0.56 & 0.75 \\
\hline Isobutyrate $(\%)$ & 16.9 & 17.8 & 18.0 & 10.1 & 0.83 & 0.16 & 0.71 \\
\hline Butyrate (\%) & 5.2 & 5.2 & 5.5 & 5.5 & 0.14 & 0.24 & 0.97 \\
\hline Isovalerate $(\%)$ & 4.8 & 4.3 & 5.9 & 4.9 & 0.25 & 0.48 & 0.62 \\
\hline Valerate $(\%)$ & 2.2 & 1.8 & 2.7 & 3.0 & 0.20 & 0.06 & 0.33 \\
\hline Succinate $(\%)$ & 1.4 & 1.1 & 1.0 & 1.2 & 0.10 & 0.45 & 0.35 \\
\hline Acetate-to-propionate ratio & 2.0 & 2.1 & 2.1 & 2.0 & 0.09 & 0.92 & 0.90 \\
\hline Total $(\mathrm{mmol} / \mathrm{L})$ & 53.5 & 50.4 & 53.4 & 44.8 & 3.28 & 0.38 & 0.64 \\
\hline \multicolumn{8}{|l|}{ Cecum } \\
\hline $\mathrm{pH}$ & 7.0 & 7.0 & 6.8 & 6.9 & 0.07 & 0.56 & 0.57 \\
\hline Acetate $(\%)$ & 53.6 & 52.5 & 49.2 & 49.7 & 1.33 & 0.23 & 0.75 \\
\hline Propionate (\%) & 17.7 & 20.5 & 16.3 & 19.5 & 0.66 & 0.85 & 0.90 \\
\hline Isobutyrate (\%) & 17.7 & 16.6 & 19.6 & 18.1 & 0.88 & 0.60 & 0.90 \\
\hline Butyrate (\%) & 5.4 & 5.3 & 4.9 & 6.5 & 0.29 & 0.34 & 0.20 \\
\hline Isovalerate $(\%)$ & 2.2 & 1.8 & 1.8 & 2.3 & 0.18 & 0.99 & 0.30 \\
\hline Valerate $(\%)$ & 1.6 & 1.6 & 1.9 & 2.5 & 0.16 & 0.04 & 0.33 \\
\hline Succinate $(\%)$ & 0.5 & 0.3 & 0.6 & 0.7 & 0.09 & 0.31 & 0.34 \\
\hline L-Lactate $(\%)$ & 1.3 & 1.1 & 1.0 & 1.2 & 0.19 & 0.56 & 0.70 \\
\hline Acetate-to-propionate ratio & 2.6 & 2.7 & 3.0 & 3.1 & 0.11 & 0.11 & 0.81 \\
\hline Total $(\mathrm{mmol} / \mathrm{L})$ & 109.0 & 87.1 & 80.0 & 97.4 & 4.89 & 0.33 & 0.05 \\
\hline
\end{tabular}

VFA (mmol/L), were similar among treatments (Table 6). These results may confirm the importance of starter intake for gastrointestinal tract development. According to Khan et al. (2007b), the volume and method of liquid feed delivery can influence the intake of solid feed before weaning, which can interfere with the onset of ruminal fermentation and development.

The increase in TS concentration in the liquid feed had a quadratic effect $(P=0.01)$ on the duodenum villi height $(\mathrm{mm})$ and a linear negative effect $(P=0.01)$ on the height $(\mathrm{mm})$ and area $\left(\mathrm{mm}^{2}\right)$ of the ileum villi (Table 7). Variations in type of nutrients and how they are provided may modify cellular proliferation, total use of nutrients by the intestine, and nutrients available to support growth. The regulation of intestinal growth is complex, and it is affected by trophic and metabolic hormones, as well as chemical and physical dietary factors (Baldwin et al., 2004; Xiao et al., 2016). According to Górka et al. (2011), adding MR to liquid feeds had negative effects on small intestine development. The authors pointed out that the maturation of the intestine epithelium, as indicated by a mitosis/apoptosis index, was decreased, which indicated a lower crypts depth and a tendency to a lower mitotic index in the small intestine epithelium as well. These findings may help explain the effects of MRP on the height (mm) and area $\left(\mathrm{mm}^{2}\right)$ of ileum villi in the present study.
All other histological variables were unaffected by the treatments (Table 7), which may indicate an adaptive response of the gastrointestinal tract for digestion and absorption of different concentrations of solids in the liquid feed (Ternouth et al., 1985). It has been postulated that ruminal physical and chemical development depends on the intake of solid feed, such as starter (Baldwin et al., 2004; Khan et al., 2007b, 2016), and the lack of differences among treatments for other histological variables could also be explained by the low starter intake.

\section{Body Composition}

Body composition of protein, fat, ash, energy, and water were not affected by treatment (Table 8). The results show that the protein:energy ratios in the liquid feed $(54,49,49$, and $48 \mathrm{~g} \mathrm{CP} /$ Mcal ME, respectively, for treatments with $13.5,16.1,18.2$, and $20.4 \% \mathrm{TS}$ ) were adequate, regardless of the amount of nutrients provided in each treatment. Similarly, Brown et al. (2005) did not find any effects of intensive high protein and energy intake from MR fed on a DM basis of $2 \% \mathrm{BW}$ and milk reconstituted to $14.1 \%$ TS on body composition compared with moderate protein and energy intake in calves at $8 \mathrm{wk}$ of age. However, Bartlett et al. (2006) reported an increase in fat per- 
Table 7. Gastrointestinal tract development of calves ( $\mathrm{n}=8$ per group) fed different TS contents in whole milk during the preweaning period ( 5 to $55 \mathrm{~d}$ of age)

\begin{tabular}{|c|c|c|c|c|c|c|c|}
\hline \multirow[b]{2}{*}{ Item } & \multicolumn{4}{|c|}{ Treatment (\% TS in whole milk) } & \multirow[b]{2}{*}{ SEM } & \multicolumn{2}{|c|}{ Contrast, $P$-value } \\
\hline & 13.5 & 16.1 & 18.2 & 20.4 & & Linear & Quadratic \\
\hline \multicolumn{8}{|l|}{ Height (mm) } \\
\hline Ruminal papillae & 2.06 & 2.27 & 1.67 & 2.05 & 0.202 & 0.75 & 0.85 \\
\hline Omasum papillae & 0.58 & 0.57 & 0.56 & 0.67 & 0.026 & 0.30 & 0.23 \\
\hline Duodenum villi & 0.51 & 0.57 & 0.64 & 0.54 & 0.018 & 0.25 & 0.01 \\
\hline Jejunum villi & 0.79 & 0.71 & 0.89 & 0.75 & 0.042 & 0.89 & 0.67 \\
\hline Ileum villi & 0.87 & 0.74 & 0.75 & 0.71 & 0.019 & 0.01 & 0.24 \\
\hline \multicolumn{8}{|l|}{ Area $(\mathrm{mm})$} \\
\hline Ruminal papillae & 2.41 & 4.13 & 2.69 & 4.09 & 0.417 & 0.37 & 0.85 \\
\hline Omasum papillae & 0.61 & 0.56 & 0.55 & 0.74 & 0.047 & 0.40 & 0.22 \\
\hline Duodenum villi & 0.15 & 0.19 & 0.19 & 0.19 & 0.008 & 0.18 & 0.26 \\
\hline Jejunum villi & 0.21 & 0.19 & 0.25 & 0.20 & 0.012 & 0.70 & 0.42 \\
\hline Ileum villi & 0.29 & 0.22 & 0.23 & 0.21 & 0.009 & 0.01 & 0.15 \\
\hline \multicolumn{8}{|c|}{ Depth of intestinal gland (mm) } \\
\hline Duodenum & 0.37 & 0.42 & 0.39 & 0.40 & 0.010 & 0.58 & 0.53 \\
\hline Jejunum & 0.39 & 0.40 & 0.39 & 0.41 & 0.011 & 0.81 & 0.82 \\
\hline Ileum & 0.49 & 0.46 & 0.48 & 0.48 & 0.010 & 0.94 & 0.34 \\
\hline \multicolumn{8}{|l|}{ Mitotic index } \\
\hline Rumen & 0.56 & 1.13 & 0.60 & 0.74 & 0.092 & 0.98 & 0.15 \\
\hline Omasum & 1.18 & 1.31 & 1.06 & 1.06 & 0.131 & 0.53 & 0.75 \\
\hline Duodenum & 13.05 & 18.00 & 17.50 & 18.50 & 1.129 & 0.16 & 0.42 \\
\hline Jejunum & 18.02 & 29.75 & 21.62 & 23.12 & 2.325 & 0.69 & 0.20 \\
\hline Ileum & 20.25 & 23.25 & 25.37 & 20.00 & 1.843 & 0.93 & 0.26 \\
\hline
\end{tabular}

centage of body gain, ADG, and feeding efficiency with an increase in liquid feed from $1.25 \%$ to $1.75 \%$ of BW (MR reconstituted to $12.5 \%$ TS); Tikofsky et al. (2001) reported that body composition was altered by diet composition under conditions of isocaloric and isonitrogenous intake, independent of rate of gain in dairy calves.

\section{CONCLUSIONS}

Increasing TS in whole milk by adding MRP up to $20.4 \%$ TS may be an option for increasing the amount of nutrients provided for dairy calves during the preweaning period. However, the increase in TS changes the starter intake without altering the passage rate, nutrient digestibility, physical and morphological pa- rameters of pre-stomachs, and intestine, as well as body composition. Furthermore, economic analyses and the cost-effectiveness of different feeding practices should be considered when devising feeding recommendations for sustainable dairy calf production.

\section{ACKNOWLEDGMENTS}

The authors thank the Coordenação de Aperfeiçoamento de Pessoal de Nível Superior (CAPES, Brasília, Brazil), Fundação de Amparo à Pesquisa do Estado de Minas Gerais (FAPEMIG, Minas Gerais, Brazil), Conselho Nacional de Desenvolvimento Científico e Tecnológico (CNPq, Minas Gerais, Brazil), and Embrapa Dairy Cattle (Minas Gerais, Brazil) for their financial support of this research.

Table 8 . Body composition of calves ( $\mathrm{n}=8$ per group) fed different TS contents in whole milk during the preweaning period ( 5 to $55 \mathrm{~d}$ of age)

\begin{tabular}{|c|c|c|c|c|c|c|c|}
\hline \multirow[b]{2}{*}{ Item } & \multicolumn{4}{|c|}{ Treatment (\% TS in whole milk) } & \multirow[b]{2}{*}{ SEM } & \multicolumn{2}{|c|}{ Contrast, $P$-value } \\
\hline & 13.5 & 16.1 & 18.2 & 20.4 & & $\begin{array}{l}\text { Linear } \\
\text { effect }\end{array}$ & $\begin{array}{c}\text { Quadratic } \\
\text { effect }\end{array}$ \\
\hline Protein (\% of DM) & 56.1 & 58.1 & 54.4 & 55.3 & 0.42 & 0.10 & 0.45 \\
\hline Fat $(\%$ of DM) & 24.1 & 23.7 & 24.7 & 24.8 & 0.43 & 0.48 & 0.78 \\
\hline Ash (\% of DM) & 13.9 & 12.4 & 14.4 & 13.7 & 0.31 & 0.62 & 0.53 \\
\hline Energy (Mcal/kg) & 5.4 & 5.4 & 5.3 & 5.3 & 0.02 & 0.34 & 0.89 \\
\hline Water $^{1}(\%)$ & 68.6 & 68.9 & 68.3 & 67.5 & 0.41 & 0.29 & 0.44 \\
\hline
\end{tabular}

${ }_{1} \%$ water $=100-\%$ total of DM. 


\section{REFERENCES}

AOAC (Association of Official Analytical Chemists). 1990. Official Methods of Analysis. Vol. I. 15th ed. Association of Official Analytical Chemists, Arlington, VA.

Azevedo, R. A., L. Araújo, D. V. L. Duarte, M. S. Cruz, S. F. Costa, N. J. F. Oliveira, E. R. Duarte, and L. C. Geraseev. 2013. Desenvolvimento do trato digestivo de bezerros leiteiros criados em sistema de aleitamento fracionado. Pesqui. Vet. Bras. 33:931-936.

Bach, A., M. Terré, and A. Pinto. 2013. Performance and health responses of dairy calves offered different milk replacer allowances. J. Dairy Sci. 96:7790-7797.

Baldwin, R. L., VI, K. R. McLeod, J. L. Klotz, and R. N. Heitmann. 2004. Rumen development, intestinal growth and hepatic metabolism in the pre- and postweaning ruminant. J. Dairy Sci. 87(E. Suppl.):E55-E65.

Bartlett, K. S., F. K. McKeith, M. J. VandeHaar, G. E. Dahl, and J. K. Drackley. 2006. Growth and body composition of dairy calves fed milk replacers containing different amounts of protein at two feeding rates. J. Anim. Sci. 84:1454-1467.

Blome, R. M., J. K. Drackley, F. K. McKeith, M. F. Hutjens, and G. C. McCoy. 2003. Growth, nutrient utilization, and body composition of dairy calves fed milk replacers containing different amounts of protein. J. Anim. Sci. 81:1641-1655.

Brown, E. G., M. J. Vandehaar, K. M. Daniels, J. S. Liesman, L. T. Chapin, D. H. Heisler, and M. S. Weber Nielsen. 2005. Effects of increasing energy and protein intake on body growth and carcass composition of heifer calves. J. Dairy Sci. 88:585-594.

Castells, L., A. Bach, A. Aris, and M. Terré. 2013. Effects of forage provision to young calves on rumen fermentation and development of the gastrointestinal tract. J. Dairy Sci. 96:5226-5236.

Chaney, A. L., and E. P. Marbach. 1962. Modified reagents for determination of urea and ammonia. Clin. Chem. 8:130-132.

Chapman, C. E., P. S. Erickson, J. D. Quigley, T. M. Hill, H. G. Bateman, F. X. Suarez-Mena, and R. L. Schlotterbeck. 2016. Effect of milk replacer program on calf performance and digestion of nutrients with age of the dairy calf. J. Dairy Sci. 99:2740-2747.

Costa, S. F., M. N. Pereira, L. Q. Melo, J. C. Resende Júnior, and M. L. Chaves. 2008. Alterações morfológicas induzidas por butirato, propionato e lactato sobre a mucosa ruminal e a epiderme de bezerros - I Aspectos histológicos. Arq. Bras. Med. Vet. Zootec. $60: 1-9$.

Davis, C. L., and J. K. Drackley. 1998. The Development, Nutrition, and Management of the Young Calf. Iowa State University Press, Ames.

De Paula Vieira, A., V. Guesdon, A. M. de Passillé, M. A. G. von Keyserlingk, and D. M. Weary. 2008. Behavioural indicators of hunger in dairy calves. Appl. Anim. Behav. Sci. 109:180-189.

Detmann, E., M. A. Souza, and S. C. Valadares Filho. 2012. Métodos para Análises de Alimentos. 1st ed. E. Detmann, M. A. Souza, and S. C. Valadares Filho, ed. Suprema, Visconde do Rio Branco, Brazil.

Dhanoa, M. S., R. C. Siddons, J. France, and D. L. Gale. 1985. A multicompartmental model to describe marker excretion patterns in ruminant faeces. Br. J. Nutr. 53:663-671.

Drackley, J. K. 2008. Calf nutrition from birth to breeding. Vet. Clin. North Am. Food Anim. Pract. 24:55-86.

Eckert, E., H. E. Brown, K. E. Leslie, T. J. DeVries, and M. A. Steele. 2015. Weaning age affects growth, feed intake, gastrointestinal development, and behavior in Holstein calves fed an elevated plane of nutrition during the preweaning stage. J. Dairy Sci. 98:6315-6326.

Ferrell, C. L., and T. G. Jenkins. 1998. Body composition and energy utilization by steers of diverse genotypes fed a high concentrate diet during the finishing period: II. Angus, Boran, Brahman, Hereford, and Tuli Sires. J. Anim. Sci. 76:647-657.

Floren, H. K., W. M. Sischo, C. Crudo, and D. A. Moore. 2016. Technical note: Use of a digital and an optical refractometer to estimate total solids in milk replacer solutions for calves. J. Dairy Sci. 99:7517-7522. http://dx.doi.org/10.3168/jds.2015-10834.

Glosson, K. M., B. A. Hopkins, S. P. Washburn, S. Davidson, G. Smith, T. Earleywine, and C. Ma. 2015. Effect of supplementing pasteurized milk balancer products to heat-treated whole milk on the growth and health of dairy calves. J. Dairy Sci. 98:1127-1135.

Górka, P., Z. M. Kowalski, P. Pietrzak, A. Kotunia, W. Jagusiak, and R. Zabielski. 2011. Is rumen development in newborn calves affected by different liquid feeds and small intestine development? J. Dairy Sci. 94:3002-3013.

Hill, T. M., H. G. Bateman, J. M. Aldrich, and R. L. Schlotterbeck. 2009. Optimizing nutrient ratios in milk replacers for calves less than five weeks of age. J. Dairy Sci. 92:3281-3291.

Hill, T. M., H. G. Bateman, J. M. Aldrich, and R. L. Schlotterbeck. 2010. Effect of milk replacer program on digestion of nutrients in dairy calves. J. Dairy Sci. 93:1105-1115.

Huhtanen, P., and U. Kukkonen. 1995. Comparison of methods, markers, sampling sites and models for estimating digesta passage kinetics in cattle fed at two levels of intake. Anim. Feed Sci. Technol. $52: 141-158$.

Jasper, J., and D. M. Weary. 2002. Effects of ad libitum milk intake on dairy calves. J. Dairy Sci. 85:3054-3058.

Kertz, A. F., and J. R. Loften. 2013. Review: A historical perspective of specific milk-replacer feeding program in the United States and effects on eventual performance of Holstein dairy calves. Prof. Anim. Sci. 29:321-332.

Kertz, A. F., L. F. Reutzel, and J. H. Mahoney. 1984. Ad libitum water intake by neonatal calves and its relationship to calf starter intake, weight gain, feces score, and season. J. Dairy Sci. 67:2964-2969.

Khan, M. A., A. Bach, D. M. Weary, and M. A. G. von Keyserlingk. 2016. Invited review: Transitioning from milk to solid feed in dairy heifers. J. Dairy Sci. 99:885-902

Khan, M. A., H. J. Lee, W. S. Lee, H. S. Kim, K. S. Ki, T. Y. Hur, G. H. Suh, S. J. Kang, and Y. J. Choi. 2007b. Structural growth, rumen development, and metabolic and immune responses of Holstein male calves fed milk through step-down and conventional methods. J. Dairy Sci. 90:3376-3387.

Khan, M. A., H. J. Lee, W. S. Lee, H. S. Kim, S. B. Kim, K. S. Ki, J. K. Ha, H. G. Lee, and Y. J. Choi. 2007a. Pre- and post-weaning performance of Holstein female calves fed milk through stepdown and conventional methods. J. Dairy Sci. 90:876-885.

Khan, M. A., D. M. Weary, and M. A. G. von Keyserlingk. 2011. Invited review: Effects of milk ration on solid feed intake, weaning and performance in dairy heifers. J. Dairy Sci. 94:1071-1081.

Kiezebrink, D. J., A. M. Edwards, T. C. Wright, J. P. Cant, and V. R. Osborne. 2015. Effect of enhanced whole-milk feeding in calves on subsequent first-lactation performance. J. Dairy Sci. 98:349-356.

Kristensen, N. B., J. Sehested, S. K. Jensen, and M. Vestergaard. 2007. Effect of milk allowance on concentrate intake, ruminal environment, and ruminal development in milk-fed Holstein calves. J. Dairy Sci. 90:4346-4355.

Larson, L. L., F. G. Owen, J. L. Albright, R. D. Appleman, R. C Lamb, and L. D. Muller. 1977. Guidelines toward more uniformity in measuring and reporting calf experimental data. J. Dairy Sci. 60:989-991.

Luna, L. G. 1968. Manual of histotegic staining methods of the Armed Forces Institute of Pathology. 3rd ed. McGraw Hill Books, New York, NY.

McGuirk, S. M. 2003. Solving calf morbidity and mortality problems. Accessed Mar. 10, 2016. http://www.vetmed.wisc.edu/dms/fapm/ fapmtools/8calf/calfmorbid.pdf.

Miller-Cushon, E. K., R. Bergeron, K. E. Leslie, and T. J. DeVries. 2013. Effect of milk feeding level on development of feeding behavior in dairy calves. J. Dairy Sci. 96:551-564.

Moore, D. A., J. Taylor, M. L. Hartman, and W. M. Sischo. 2009 Quality assessments of waste milk at a calf ranch. J. Dairy Sci. 92:3503-3509.

Omidi-Mirzaei, H., M. Khorvash, G. R. Ghorbani, B. Moshiri, M. Mirzaei, A. Pezeshki, and M. H. Ghaffari. 2015. Effects of the step-up/step-down and step-down milk feeding procedures on the performance, structural growth, and blood metabolites of Holstein dairy calves. J. Dairy Sci. 98:7975-7981.

Overvest, M. A., R. Bergeron, D. B. Haley, and T. J. DeVries. 2016. Effect of feed type and method of presentation on feeding behav- 
ior, intake, and growth of dairy calves fed a high level of milk. J. Dairy Sci. 99:317-327.

Pettyjohn, J. D., J. P. Everett Jr., and R. D. Mochrie. 1963. Responses of dairy calves to milk replacer fed at various concentrations. J. Dairy Sci. 46:710-714.

Siegfried, B. R., H. Ruckemann, and G. Stumpf. 1984. Method for the determination of organic acids in silage by high performance liquid chromatography. Landwirtsch. Forsch. 37:298.

Silper, B. F., A. M. Q. Lana, A. U. Carvalho, C. S. Ferreira, A. P. S. Franzoni, J. A. M. Lima, H. M. Saturnino, R. B. Reis, and S. G. Coelho. 2014. Effects of milk replacer feeding strategies on performance, ruminal development, and metabolism of dairy calves. J. Dairy Sci. 97:1016-1025.

Silva, A. L., M. I. Marcondes, E. Detmann, F. S. Machado, S. C. Valadares Filho, A. S. Trece, and J. Dijkstra. 2015. Effects of raw milk and starter feed on intake and body composition of Holstein $\times$ Gyr male calves up to 64 days of age. J. Dairy Sci. 98:2641-2649.

Sweeney, B. C., J. P. Rushen, D. M. Weary, and A. M. B. de Passillé 2010. Duration of weaning, starter intake, and weight gain of dairy calves fed large amounts of milk. J. Dairy Sci. 93:148-152.

Ternouth, J. H., I. J. F. Stobo, J. H. B. Roy, and A. W. Beattie. 1985. The effect of milk substitute concentration upon the intake, digestion and growth of calves. Anim. Prod. 41:151-159.
Terré, M., M. Devant, and A. Bach. 2006. Performance and nitrogen metabolism of calves fed conventionally or following an enhanced growth feeding program during the preweaning period. Livest. Sci. 105:109-119.

Terré, M., M. Devant, and A. Bach. 2007. Effect of level of milk replacer fed to Holstein calves on performance during the preweaning period and starter digestibility at weaning. Livest. Sci. 110:82-88.

Terré, M., C. Tejero, and A. Bach. 2009. Long-term effects on heifer performance of an enhanced growth feeding programme applied during the pre-weaning period. J. Dairy Res. 76:331-339.

Tikofsky, J. N., M. E. Van Amburgh, and D. A. Ross. 2001. Effect of varying carbohydrate and fat content of milk replacer on body composition of calves. J. Anim. Sci. 79:2260-2267.

Xiao, J. X., G. M. Alugongo, R. Chung, S. Z. Dong, S. L. Li, I. Yoon, Z. H. Wu, and Z. J. Cao. 2016. Effects of Saccharomyces cerevisiae fermentation products on dairy calves: Ruminal fermentation, gastrointestinal morphology, and microbial community. J. Dairy Sci. 99:5401-5412.

Yavuz, E., N. Todorov, G. Ganchev, and K. Nedelkov. 2015. The effect of feeding different milk programs on dairy calf growth, health and development. Bulg. J. Agric. Sci. 21:384-393. 